\title{
Okul Öncesi ve Sınıf Öğretmenliği Lisans Programlarının Çocuğun Bütünsel Gelișimi Açısından Değerlendirilmesi
}

\author{
Halil KAMIŞLI* \\ Elif KARSLI ÇALAMAK ${ }^{* *}$ \\ Sinan OLKUN ${ }^{* * *}$
}

\begin{abstract}
Öz: Gelişimsel olarak aynı dönemde bulunan ve örtüşen yaş gruplarındaki çocuklara öğretmenlik yapan okul öncesi ve sınıf öğretmenlerinin ortak mesleki temel yeterlikler ile birlikte birbirini tamamlayan mesleki donanımlara sahip olmaları beklenir. Bu çalışma, erken çocukluk dönemi çocukları ile çalışacak olan okul öncesi ve sınıf öğretmeni adaylarının, çocukların farklılıklardan doğan potansiyellerini fark edip ihtiyaçlarını karşılayabilmeye yönelik muhtemel yeterliklerini, 2018-2019 öğretim yılında uygulamaya konulan yükseköğretim öğretmenlik programları ekseninde incelemiştir. Bu inceleme sürecinde, çocukların çok yönlü ihtiyaçlarını karşılamayı önceleyen bütünsel çocuk yaklaşımı rehber olarak kullanılmıştır. Araştırma sonucunda, iki programın çocuğu tanıma ve çocuğun çok yönlü ihtiyaçlarını karşılama alanlarında farklılaştığı ve gelişimsel olarak aynı dönemde olan çocuklara hitap ediyor olmalarına rağmen, bu benzerliğin ders içeriklerine yansımadığı sonuçlarına ulaşılmıştır. Bu durum ışı̆̆ında lisans öğretmen yetiştirme programları için önerilerde bulunulmuştur.
\end{abstract}

Anahtar Sözcükler: Bütünsel Çocuk, Gelişime Uygun Eğitim, Bireysel ve Kültürel Farklılıklar, Bireyselleştirme, Öğretmen Eğitimi, Okul Öncesi Eğitimi, Sınıf Eğitimi

\section{Whole Child Approach Guided Evaluation of Pre-School and Primary School Teacher Education Programs in Turkey}

\begin{abstract}
Early childhood teacher education programs in Turkey are divided into two different tracks. While one track offers certification in teaching children from birth-to-kindergarten, the latter certifies teachers to teach from $1^{\text {st }}$ through $4^{\text {th }}$ grade. However, with a recent school entrance policy change, the age of children enrolled in kindergarten and first-grade classes have widely overlapped. In this research, we analyzed these teacher education programs to understand if and how teachers are being prepared to fulfill the needs of children regardless of their age, individual and cultural differences. In doing so, we employed document analysis to investigate national early childhood teacher education undergraduate programs for both tracks. Guided by the whole child approach, our analysis revealed that these two tracks widely differ in equipping teachers with knowledge about childhood and child development in favor of the birth-to-kindergarten track. Another result of the study manifested discontinuities among the tracks, which overlook the process-oriented nature of children's development and learning.
\end{abstract}

Keywords: Whole Child, Developmentally Appropriate Practices, Individual and Cultural Differences, Differentiation, Teacher Education, Early Childhood Education, Primary Education

*Uluslararası Final Üniversitesi, Eğitim Bilimleri Fakültesi, E.P.Ö., Kyrenia, KKTC, via Mersin 10 TR., e-posta: halil.kamisli@final.edu.tr, ORCID: https://orcid.org/0000-0001-6715-431X

** University of South Carolina, Faculty of Education, Early Childhood Education Program, Columbia, USA, e-posta: karsli@mailbox.sc.edu, ORCID: https://orcid.org/0000-0001-7280-994X

*** Uluslararası Final Üniversitesi, Eğitim Bilimleri Fakültesi, İlköğretim Matematik Öğretmenliği Bölümü, Kyrenia, KKTC, via Mersin 10 TR., e-posta: sinan.olkun@final.edu.tr, ORCID: https://orcid.org/0000-0003-3764-2528 
Çocukluğun insan yaşamında önemli bir yer tutmasının nedenlerinden biri erken çocukluk dönemi deneyimlerinin ilerleyen yıllarda insan gelişimini pek çok yönüyle etkiliyor olmasıdır. Erken çocukluk dönemi felsefi tartışmaların, gözlemsel ve deneysel çalışmaların farklı şekillerde her daim konusu olmuştur. Çocukluğun ne anlam ifade ettiği, çocukların öğrenme süreçleri ve yaşamın ilk yıllarında çocuklara sağlanan eğitimin ne şekillerde olması gerektiğine dair tartışmalar Antik Yunan felsefecilerine kadar dayanmaktadır. 1900'lü yıllardan sonra ise Dewey, Piaget, Vygotsky gibi alana yön vermiş kuramcıların gözlemsel araştırmaları ile çocuk gelişimine dair önemli bilgiler elde edilmiştir. Buna paralel olarak erken çocukluk dönemine dair çalışmalar hız kazanmıştır. 21. yüzyıl itibariyle de erken çocukluk dönemi çocuklarının gelişimi, erken dönem eğitiminin niteliği ve bu dönem çocukları ile çalışan öğretmenlerin yeterlilik ve deneyimlerine dair disiplinler arası bir yaklaşımla gerçekleştirilmekte olan çalışmalar alanyazına girmiştir (Saracho ve Spodek, 2013).

Erken çocukluk döneminde, çocukların eğitim sorumluluğunu üstlenecek öğretmenleri odak noktasına alan ulusal ve uluslararası pek çok araştırma mevcuttur. Bu araştırmalar, çocukların gelişim ve öğrenmeleri ile öğretmenlerinin mesleki donanımları arasında sıkı bir ilişki olduğunu göstermektedir (Barnett, 2003; Whitebook, 2003). Öğretmenlerin mesleki yeterliklerinin önemli ölçüde kazanıldığı bilinen hizmet öncesi eğitim döneminde, öğretmen yetiştirmeye yönelik çaba ve uygulamaların doğası ve niteliği her daim araştırmaya değer bir konu olmuştur. Bu çalışma, Türkiye'de erken çocukluk dönemi çocukları ile çalışacak olan okul öncesi ve sınıf öğretmeni adaylarının hizmet öncesi dönem lisans eğitimlerine odaklanmaktadır.

Erken çocukluk döneminin doğumdan yaklaşık sekiz yaşına kadar olan dönemi kapsadığına dair genel bir kanının varlığı kabul edilebilir (Copple ve Bredekamp, 2009). Bu durumun temel sebeplerinden biri, yaşamın ilk yıllarında bilişsel, sosyal-duygusal, dil ve fiziksel gelişim hızının yaşamın diğer dönemlerine oranla daha hızlı olmasıdır. Gelişim alanlarının temelinin yaklaşık 0-8 yaş arasını kapsayan dönemde atılması, bir diğer deyişle, erken yaş deneyimlerin, yaşamın ilerleyen yıllarında edinilen deneyimler üzerindeki yordayı gücü de bu durumun diğer temel sebeplerinden biridir (Copple ve Bredekamp, 2009). Erken çocukluk döneminin son derece önemli olması sebebiyle, küçük çocuklar ile çalışacak öğretmen adaylarının insan gelişiminin erken çocukluk dönemi hakkında bütüncül şekilde bilgi sahibi olmaları ve çocukların öğrenme potansiyellerini fark edip rehberlik edecek şekilde donanımlı olmaları gerekmektedir (Saracho ve Spodek, 2007).

Erken çocukluk döneminin, kapsadığı yaş grubu da dâhil olmak üzere tanımı daha evrensel şekilde yapılırken, erken çocukluk dönemindeki çocuklara sunulan müfredatlar ve bu dönem çocukları ile çalışan öğretmenlerden beklenen yeterlik ve nitelikler, ülkeden ülkeye ve zaman içerisinde farklılıklar gösterebilmektedir. Türkiye'yi düşündügüumüzde ise, bu konuda kısa zaman dilimleri içerisinde dahi büyük farklılıklar olabildiği gözlenmektedir. Örneğin, Türkiye'de sık sık gündeme gelmesi ve zaman zaman pilot uygulamalar ile desteklenmesine rağmen okul öncesi eğitim halen zorunlu eğitim kapsamında değildir. Bazı çocuklar anaokulu eğitimi alırken bazıları almadan doğrudan ilkokula gidebilmektedir. Bu durum sınıfları hazır bulunuşlukları farklı olan çocukların bir arada olduğu heterojen dokulara dönüştürmektedir.

Diğer yandan ilkokul birinci sınıfa başlama yaşı 2019 yılı Eylül ayı itibariyle 69 ay olarak yeniden düzenlenmiş ve Eylül ayı itibariyle 66-71 ay aralığındaki çocukların ilkokul birinci sınıfa başlaması ise veli kararına bırakılmıştır (Milli Eğitim Bakanlığı Okul Öncesi Eğitim ve İlköğretim Kurumları Yönetmeliği, 2019). Bir diğer ifadeyle, mevcut durumda bir okul öncesi öğretmeni sınıfında 71-80 ay aralığında çocuklar ile okul öncesi eğitimi müfredatı ile çalışabiliyorken, bir sınıf öğretmeni ise, yaşı daha küçük olan, 66-75 ay aralığındaki çocuklara sınıf öğretmenliği müfredatı ile eğitim yapar duruma gelmiştir. Özetle, geniş yaş aralığındaki çocukların aynı sınıflarda olabilmesi ile mevcut sınıflar önceki yıllara göre farklı ve daha karma bir yaş grubu dokusuna bürünmüştür. Öğretmen yeterlikleri açısından baktığımızda, yaş grupları ve önceden okul öncesi eğitim alıp almama durumlarına göre farklı olan çocukların aynı sınıflarda olması, okul öncesi ve sınıf öğretmenliği lisans programlarında ele alınması gereken durumlar olarak karşımıza çıkmaktadır.

Çocuk gelişiminin yaş ile ilişkili olan fakat yalnızca yaşa dayalı bir süreç olmadığı bilgisinden hareketle, erken çocukluk döneminde benzer yaş grubunda olan çocuklar doğum ile getirdikleri farklılıkların yanı sıra içine doğdukları aile kültürü, çevre ve sosyo-ekonomik dinamiklerin etkisi ile potansiyel ve ihtiyaçları 
bakımından farklılık gösterebilmektedirler (Souto-Manning, 2013). Günümüzde Türkiye bağlamında temel eğitim sınıflarını göz önüne aldığımızda, farklı yaşlarda olan, bireysel ve kültürel farklılıklara sahip çocukların aynı sınıflarda olması ile hem gelişimsel hem de eğitime hazır bulunuşlukları açısından, bir başka ifadeyle, ihtiyaç duydukları destek ve öğrenme potansiyelleri açısından aralarında farklar olacağı düşünülebilir.

Çocukların mevcut yaş, bireysel ve sosyo-kültürel farklılıklarının yanı sıra, mülteci çocukların varlığı da göz önüne alındığında, sınıfların oldukça heterojen dokulara sahip oldukları söylenebilir. Türkiye'de devlet okullarına devam eden ve sayısı 600.000'e yaklaşan mülteci ve yabancı statüsündeki çocukların, 2019 yılı itibariyle yaklaşık 400.000'i temel eğitim kapsamında eğitim almaktadır (MEB Hayat Boyu Öğrenme Genel Müdürlüğü Göç ve Acil Durum Eğitim Daire Başkanlığı, 2019). Özetle, günümüzde Türkiye'de okul öncesi ve ilkokul sınıfları yaş, dil ve kültür farklılıklarını barındıran, daha önce hiç olmadığı kadar çokkültürlü dokulara bürünmüştür. Bu tür yapılar içerisinde, çocukların her koşulda potansiyellerini fark edebilecek ve ihtiyaçlarına karşılık verecek çok yönlü ve donanımlı öğretmenler ile karşılaşmaları gerekmektedir (Nieto, 2003). Çünkü çocuklar eşitsizliklerin gözlenip önlenerek, farklılıklarına değer verilip desteklendiği durumlarda başarı gösterme potansiyeline sahiptirler (Bekman, 1998).

Türkiye'de erken çocukluk döneminde olan çocukların eğitiminden sorumlu öğretmen grubu okul öncesi ve sınıf öğretmenliği alanından mezun öğretmenlerdir. Gelişimsel olarak aynı dönemde bulunan ve örtüşen yaş gruplarındaki çocuklara öğretmenlik yapan okul öncesi ve sınıf öğretmenlerinin ortak mesleki temel yeterlikleri ile birbirini bütünleyen mesleki donanımlarının olması beklenir. Bu çalışma, Türkiye'de okul öncesi ve sınıf öğretmenliği lisans programlarının benzerlik ve farklılıklarını ortaya koyarak, erken çocukluk dönemi çocukları ile çalışacak olan okul öncesi ve sınıf öğretmenlerinin, çocukların farklılıklardan doğan potansiyellerini fark edip ihtiyaçlarını karşılayabilmeye yönelik muhtemel yeterliklerini, yükseköğretim öğretmenlik programları ekseninde inceleme ve tartışmayı amaçlamaktadır.

\section{Alanyazın: Okul Öncesi ve Sınıf Öğretmenliği Öğretmen Yetiştirme Programları}

Türkiye'deki öğretmen yetiştirme programlarının, uluslararası öğretmen yetiştirme standartlarına uygun aynı zamanda ülkedeki ekonomik, sosyal ve kültürel bağlamı da dikkate alan bir yapıda olması ve öğretmen adaylarının muhtemel gelecek ihtiyaçlarına gerçekçi cevaplar verebilme potansiyeline sahip olması gerekir (Çakıroğlu ve Çakıroğlu, 2003; Küçükahmet, 2007; Şimşek ve Yıldırım, 2001). Türkiye'de öğretmen yetiştirmeye yönelik uygulamaların, öğretmen niteliğini hizmet öncesi dönem dâhil olmak üzere, toplumsal değerler, uluslararası standartlar ve 21. yüzyıl becerileri göz önüne alarak gerçekleştirilmesi, eğitim politikası belgeleri ve kalkınma planlarında bulunan hedefler arasındadır (Çalışıcı, 2019). Bu hedef doğrultusunda, öğretmen eğitimi programlarında sunulan derslerin zamanla içeriklerinin yenilenmesi, özel alan bilgisi derslerinin, genel kültür ve genel yetenek dersleri ile dengesinin güncellenmesi, uygulamaya yönelik derslerin Milli Eğitim Bakanlığı'na bağlı okullar ile kurulan işbirlikleri ile öğretmen yetiştirme programlarına dâhil edilmesi gibi adımlar atılmaktadır (Çalışıcl, 2019). Türkiye'de öğretmen eğitimini desteklemek adına geliştirilen bu tür uygulamaların verimliliği, bir başka deyişle, öğretmen adaylarının ve öğrencilerin ihtiyaçlarını karşılamadaki yeterliliği araştırılmaya değer bir konudur.

Hizmet öncesi öğretmen eğitimi konusu uluslararası alanyazında da oldukça sık ele alınan bir konudur. Örneğin, Blank (2010) ve Saracho ve Spodek (2007) Amerika Birleşik Devletleri'nde son yıllarda erken çocukluk eğitimi öğretmenlerini yetiştirmeye yönelik yapılan çalışmaları incelemişlerdir. Bu çalışmalardaki ortak temalar, küçük çocuklar ile çalışan öğretmenlerin yükseköğretim mezunu olmalarının, erken çocukluk eğitimi özel alan bilgisine sahip ve erken çocukluk öğretmeni kimliğini benimsemiş olmalarının hem öğretmen adayları hem de gelecekteki öğrencileri için olumlu etkiler yarattığını göstermektedir. Bu çalışmalardaki bir diğer vurgu ise son yıllarda öğretmen eğitimi programlarında gelişimsel uygunluk uygulamaları (Developmentally Appropriate Practices [DAP]) eksenindeki en iyi uygulamalar (best practices) felsefesinin küçük çocukların eğitimi konusunda yaygın bir etkiye sahip olduğudur. Benzer şekillerde, Türkiye'de de okul öncesi ve sınıf öğretmenlerinin lisans seviyesinde ne tür bir eğitime sahip olmaları gerektiği, öğretmen eğitiminde pedagojik formasyon ve açık öğretim eğitimi opsiyonları sıkça tartışılan konular olmuştur. Özellikle okul öncesi öğretmenliği programlarında gelişimsel uygunluk bakış açısının ülkemizde de yaygın bir etkiye sahip olduğu ve Türkiye'de okul öncesi öğretmen adaylarının genelinin çocuk merkezli bir felsefe 
olan gelişimsel uygunluk bakış açısını benimsemekte oldukları görülür (Erdiller Akın, 2013; Erdiller ve McMullen, 2003).

Okul öncesi ve sınıf öğretmenliği lisans programları zamanla yenilendikçe, programları çeşitli değişkenler açısından inceleyen çalışmalar alanyazında yer almaktadır. Bu çalışmaları incelediğimizde, sınıf öğretmenliğ̈i programının okul öncesi öğretmenliği programına göre daha çok araştırmaya konu edilmiş olduğu görülmektedir. Alanyazında, sınıf öğretmenliği lisans programı içeriğinin genel hatlarıyla kendi içerisinde (Çoban, 2011; Yurdakal, 2018) ve programı özel alan öğretmen yeterlilikleri açısından (Çakmak ve Civelek, 2013) inceleyen çalışmalar mevcuttur. Güncel okul öncesi öğretmenliği programı ise, dil becerileri eğitimi açısından incelenerek bir çalışmaya konu olmuştur (Karagöl, 2018). Hem okul öncesi (Bartan, 2019; Uysal, Ozen Altınkaynak, Taşkın, Akman ve Çağlayan Dinçer, 2016) hem de sınıf öğretmenliği programlarını (Akdoğdu ve Uşun, 2017; Çaycı, 2011; Kara, Demir, Arcagök ve Çavuş, 2018; Kılıç Özmen, 2019), öğretmen ve öğretmen adaylarının fikirleri doğrultusunda inceleyen çalışmalar, bu programları birebir deneyimleyen kişilerin fikir ve inanışlarını yansıttığ ${ }_{1}$ için derinlikli bir analiz sunmuştur.

Alanyazında, sınıf öğretmenliği programını güncel bir konu olan çok kültürlülük (Kamışlı, 2019) ve kültürel değerlere duyarlı eğitim açısından (Karataş, 2018) inceleyerek önerilerde bulunan çalışmalar da mevcuttur. Bununla birlikte, son yıllarda, okul öncesi (Aykaç, 2018; Küçükoğlu ve Kızıltaş, 2012) ve sınıf öğretmenliği programlarını (Ergün ve Ersoy, 2014) Almanya, Belçika, Fransa, Hollanda, İngiltere, İtalya, Romanya ve Rusya gibi ülkelerdeki öğretmenlik programları ile karşılaştırmalı olarak inceleyen çalışmaların varlığı da göze çarpmaktadır.

Özetle, alanyazındaki mevcut program incelemesi çalışmaları göz önüne alındığında, bu makalede paylaşılan araştırmanın, güncel okul öncesi ve sınıf öğretmenliği programını, erken çocukluk eğitiminin bütüncül felsefesi doğrultusunda birbiri ile ilişkili olarak inceliyor olması özgün bir değer taşımaktadır. Bir sonraki bölümde, bu araştırmada yer alan öğretmenlik programlarının değerlendirilmesine rehberlik eden bakış açısı ele alınmaktadır.

\section{Kavramsal Çerçeve: Çocuk Gelişimi ve Eğitimine Bütüncül Bir Yaklaşım}

Erken çocukluk eğitimi alanında öğretmen yetiştirme konusu, sahip olunan çocukluk algısı ve çocukların potansiyel ve ihtiyaçlarına dair benimsenen kuramsal fikirler ile birebir ilişkilidir. Bir diğer deyişle, "Nasıl öğretmenler yetiştirmek istiyoruz?" sorusu ile birlikte cevaplanması gereken soruların arasında "Çocukluk algımız nedir? Çocukluk dönemine dair fikir ve varsayımlarımız nelerdir? Çocukların öğrenme süreçlerine dair benimsediğimiz yaklaşımlar nelerdir?" gibi sorular yer alır. Mevcut çalışmada, okul öncesi ve sınıf öğretmeni yetiştirme programları bu sorular çerçevesinde, çocuk merkezli bir bakış açısıyla ele alınmıştır. Bu sürece çocukluğun doğasına uygun hareket etmeyi ve çocukların çok yönlü ihtiyaçlarını karşılamayı önceleyen bütünsel çocuk (whole child) yaklaşımı rehberlik etmiştir.

Bütünsel çocuk yaklaşımı çocuğun bilişsel, sosyal, duygusal, beden ve dil gelişimini birbirinden ayrılmaz bütüncül bir sistem olarak görür. Çocuğun yüksek yarar ve esenliğini gözeten bu yaklaşım, her çocuğun kendine özgü bir gelişim ritmi ve hızı olduğunu kabul eder. Çocuğun gelişim hızına saygı göstererek, çevresi ile etkileşim halinde, anlamlı yaşantılar edinerek çok yönlü bilgi ve beceriler edinmesi için uygun ortamlar hazırlanması gerektiğini savunur (Crosnoe, Bonazzo ve $\mathrm{Wu}, 2015$; Puma ve diğerleri, 2010). Bütünsel yaklaşım, çağdaş eğitimin tarihi öncülerinden Pestalozzi'nin, eğitimin çocuğun zihin, beden ve ruhsal-manevi (head, hands, heart) birlikteliğine cevap vermesi gerektiğini öne süren felsefesine dayanmaktadır. Günümüzde ise bu yaklaşımın yansımaları, eğitimi doğa ile iç içe, çocuğun hayal gücü, yaratıcılık ve entelektüel gelişimini bütünleştirilmiş şekilde ele alan Rudolf Steiner'ın Waldorf felsefesini rehber alan eğitim programlarında görülebilir.

Bütünsel çocuk yaklaşımı, erken yaş grubu ile çalışacak öğretmenlerin sahip olması gereken donanım ve sorumlulukları belirleme sürecine rehberlik edebilir. Bu bakış açısına göre, küçük çocuklar ile çalışacak öğretmenler, çocukları sadece akademik yönleriyle desteklemeyip onlara yaşama dair çok yönlü beceriler

kazandırabilecek yetkinliklere sahip olmalıdır. Bir diğer deyişle, öğretmenler, akademik öğrenmeler, günlük yaşama dair sosyal ve duygusal yetenekler, müzik, sanat, spor gibi alanlara yönelik beceriler arasında bir 
hiyerarşi belirlemeden, çocuğun çok yönlü gelişimine olanak sağlayacak eğitim ortamlarının tasarlayıcısı olmalıdır (Olkun, Deniz, Toran, Sarı ve Kamışlı, 2019). Bunun yanı sıra, öğretmenlerin her çocuğun gelişim hızının kendine özgü olabileceği farkındalığı ile çocukların bireysel ve kültürel farklılıklarından kaynaklanan ihtiyaçlarına cevap verebilecek donanımlarla mezun olmalarını gerektirir. Özetle, çocuk gelişim ve eğitimine yönelik bütünsel bakış açısı, ideal öğretmen donanım ve yetkinliklerini tahayyül etmemize yardım etmekle birlikte, okul öncesi ve sınıf öğretmenliği programlarını çocuk merkezli şekillerde inceleyebilmemize olanak sağlar.

\section{Yöntem}

Okul öncesi öğretmenliği ve sınıf öğretmenliği programlarını bütünsel çocuk perspektifinden inceleyen bu çalışmada, doküman incelemesi yöntemi (Yıldırım ve Şimşek, 2005) kullanılmıştır. Araştırma kapsamında doküman incelemesi yapılırken aşağıda yer alan basamaklar gerçekleştirilmiştir.

1. Dokümana ulaşma ve orijinalliğinin kontrol edilmesi: Yükseköğretim Kurulu (YÖK) tarafından Ankara Üniversitesi basımevinde bastırılmış, 2018-2019 akademik yılından itibaren uygulamaya konulan “Öğretmen Yetiştirme Lisans Programları" adlı kitapçık çalışmada kullanılacak doküman olarak belirlenmiştir. Elde edilen dokümanın orijinalliğini kontrol etmek amacı ile YÖK resmî sitesinde güncellenen öğretmenlik programları tek tek incelenmiş ve dokümanın güncel ve doğru bilgiler içerdiğinden emin olunmuştur.

2. Dokümanların anlaşılması ve verilerin sınıflandırılması: İlk aşamada, araştırma kapsamına alınan okul öncesi ve sınıf öğretmenliği programlarında yer alan dersler ayrı ayrı incelenerek, bu dersler (a) mesleki bilgi, (b) genel kültür ve (c) alan eğitimi başlıkları altında listelenmiştir. Bu aşamada, iki programın ortak ve farklı dersleri belirlenerek bu üç başlığa göre tablolaştırılmıştır (bknz. Tablo 1). Bu üç başlık altındaki derslerdeki ortaklığın sadece okul öncesi ve sınıf öğretmenliği programlarına ait olup olmadığının belirlenmesi için diğer tüm öğretmenlik programları da aynı şekilde incelenmiştir. İkinci aşamada, iki programa ait ders isim ve içerikleri tablolaştırılarak listelenmiştir. Bu aşamada, ismi ve içeriği aynı olan dersler ile birlikte, ismi farklı ancak içeriği aynı olan dersler tespit edilmiştir. Üçüncü aşamada ise derslerin ismi ile birlikte içerikleri de göz önüne alınarak, ait oldukları branşlara göre tablolaştırılmıştır (bknz. Tablo 2). Dördüncü aşamada, üç alanla ilgili seçmeli dersler incelenmiş isim ve içerik olarak ortak ve farklı olan dersler listelenmiştir (bknz. Tablo 3).

3. Verilerin analiz edilmesi: Elde edilen veriler, benzerlik ve farklılık durumlarına göre incelenmiş, sayısallaştıılmış, yüzdelik olarak benzeşim oranları belirlenmiş, dersler isim ve içerikleri göz önüne alınarak araştırma sorusunun cevaplanmasına yardımcı olabilecek başlıklar altında kategorize edilmiştir. Elde edilen verilere dayalı olarak iki program ile ilgili çıkarımlarda bulunulmuştur.

\section{Bulgular}

Bulgular okul öncesi ve sınıf öğretmenliği öğretmen yetiştirme programlarının dersler bakımından bütünsel çocuk yaklaşımına uygunluğu ve öğretmen donanımları açısından birbirini tamamlama özelliklerini ne derecede taşıdığı sorusuna yanıt verecek şekilde düzenlenmiştir.

\section{İki Programa Yönelik Ders Yoğunluklarının Dağılımı ve Ortak Yönleri}

Tablo 1'de iki programa yönelik ders yoğunluklarının dağılımı ve ortaklık durumlarına ilişkin sayısal değerler verilmektedir. Tablo 1 incelendiğinde, iki program için ders yoğunluklarının oldukça benzer olduğu görülmektedir. Derslerin alanlara göre dağılımı ise, Meslek Bilgisi \%35, Genel Kültür \%19, Alan Eğitimi \%46 şeklindedir. Okul öncesi öğretmenliği ve sınıf öğretmenliği programlarında meslek bilgisi ve genel kültür dersleri ortak olup toplam ders saatleri şu şekildedir: Meslek bilgisi 44 saat teorik, 12 saat uygulamalı, genel kültür 26 saat teorik, 2 saat uygulamalı. 
Tablo I

Her iki programdaki ders dağılımları

\begin{tabular}{|c|c|c|c|c|c|c|c|c|c|}
\hline \multirow[b]{2}{*}{ Dersler } & \multicolumn{2}{|c|}{ Ders Yoğunluğu } & \multicolumn{2}{|c|}{ Toplam ders sayısı } & \multirow{2}{*}{$\begin{array}{l}\text { İsmi ve } \\
\text { içeriği iki } \\
\text { programda } \\
\text { ortak dersler }\end{array}$} & \multirow{2}{*}{$\begin{array}{l}\text { İsmi farklı } \\
\text { fakat içeriği } \\
\text { ortak } \\
\text { dersler }\end{array}$} & \multirow{2}{*}{$\begin{array}{l}\text { Branşları } \\
\text { ortak dersler }\end{array}$} & \multicolumn{2}{|c|}{ Farklı olan } \\
\hline & $\begin{array}{l}\text { Okul } \\
\text { Öncesi } \\
\text { Öğr. } \\
\end{array}$ & $\begin{array}{l}\text { Sınıf } \\
\text { Öğr. }\end{array}$ & $\begin{array}{l}\text { Okul } \\
\text { Öncesi Öğr. }\end{array}$ & Sinıf Öğr. & & & & $\begin{array}{l}\text { Okul } \\
\text { Öncesi } \\
\text { Öğr. } \\
\end{array}$ & $\begin{array}{l}\text { Sınıf } \\
\text { Öğr. }\end{array}$ \\
\hline $\begin{array}{l}\text { Genel } \\
\text { Kültür }\end{array}$ & $\% 19$ & $\% 19$ & $\begin{array}{l}\text { Dördü } \\
\text { seçmeli } \\
\text { toplam } 12 \\
\end{array}$ & $\begin{array}{l}\text { Dördü } \\
\text { seçmeli } \\
\text { toplam } 12\end{array}$ & Hepsi & Yok & & Yok & Yok \\
\hline $\begin{array}{l}\text { Meslek } \\
\text { Bilgisi }\end{array}$ & $\% 35$ & $\% 35$ & $\begin{array}{l}\text { Altısı } \\
\text { seçmeli } \\
\text { toplam } 22 \\
\end{array}$ & $\begin{array}{l}\text { Altısı } \\
\text { seçmeli } \\
\text { toplam } 22 \\
\end{array}$ & Hepsi & Yok & & Yok & Yok \\
\hline $\begin{array}{l}\text { Alan } \\
\text { Eğitimi }\end{array}$ & $\% 46$ & $\% 46$ & $\begin{array}{l}\text { Altısı } \\
\text { seçmeli } \\
\text { toplam } 25\end{array}$ & $\begin{array}{l}\text { Altısı } \\
\text { seçmeli } \\
\text { toplam } 26\end{array}$ & 1 & 1 & 7 & 10 & 6 \\
\hline
\end{tabular}

Okul Öncesi Öğretmenliği programında alan eğitimi dersleri kapsamında 64 saat teorik olmak üzere toplam 19 ders mevcuttur. Sınıf Öğretmenliği programında ise, alan eğitimine ait 64 saat teorik, 2 saat uygulamalı olmak üzere toplam 20 ders mevcuttur. Her iki bölümde de 6 adet alan seçmeli ders vardır. İki programa ilişkin alan eğitimine yönelik bulgulara bakıldığında, ismi ve içeriği ortak ders sayısının 1, ismi farklı fakat içeriği ortak olan ders sayısının da 1 olduğu görülür. Aynı branşa ait (matematik, fen bilimleri, müzik gibi belirli alanlara ait dersler) ders sayısının 7 ve tümüyle farklı derslerin sayısının ise 6 (Sınıf Öğretmenliği) ve 9 (Okul Öncesi Öğretmenliği) olduğu görülür.

\section{İki Programda Bulunan Alan Eğitimi Derslerine Yönelik Bulgular}

İki programda bulunan alan eğitimi derslerine yönelik elde edilen bulgulara Tablo 2' de yer verilmiştir. Alan eğitimi dersleri içerisinde Karakter ve Değer Eğitimi dersi iki programda da ortak olup aynı içeriğe sahiptir. Drama eğitimi konusunda her iki programda, Erken Çocukluk Eğitiminde Drama ve İlkokulda Drama isimli aynı içeriğe sahip birer ders mevcuttur.

Tablo II

İki Programin Alan Eğitimi Derslerine Yönelik Bulgular

\begin{tabular}{|c|c|c|c|c|c|c|}
\hline \multirow{2}{*}{$\begin{array}{l}\text { İçerik ve } \\
\text { İsmi Ortak } \\
\text { Olan }\end{array}$} & \multicolumn{2}{|c|}{$\begin{array}{c}\text { İsmi Farklı, İçeriği Ortak } \\
\text { Dersler }\end{array}$} & \multicolumn{2}{|c|}{$\begin{array}{l}\text { İsim ve İçerikleri Farklı, Branşları Ortak } \\
\text { Dersler }\end{array}$} & \multicolumn{2}{|c|}{ Tümüyle Farklı Olan Dersler } \\
\hline & $\begin{array}{l}\text { Okul } \\
\text { Öncesi Öğr. }\end{array}$ & Sınıf Öğr. & Okul Öncesi Öğr. & Sinıf Öğr. & Okul Öncesi Öğr. & Sınıf Öğr. \\
\hline \multirow{9}{*}{$\begin{array}{l}\text { Karakter ve } \\
\text { Değer } \\
\text { Eğitimi }\end{array}$} & \multirow{9}{*}{$\begin{array}{l}\text { Erken } \\
\text { Çocukluk } \\
\text { Eğitiminde } \\
\text { Drama }\end{array}$} & \multirow{9}{*}{$\begin{array}{l}\text { İlkokulda } \\
\text { Drama }\end{array}$} & $\begin{array}{l}\text { Erken Çocuklukta } \\
\text { Oyun Gelişimi ve } \\
\text { Eğitimi }\end{array}$ & $\begin{array}{l}\text { Oyun ve Fiziki } \\
\text { Etkinlikler } \\
\text { Öğretimi }\end{array}$ & $\begin{array}{l}\text { Erken Çocukluk } \\
\text { Eğitimine Giriş }\end{array}$ & $\begin{array}{l}\text { Hayat } \text { Bilgisi } \\
\text { Öğretimi }\end{array}$ \\
\hline & & & $\begin{array}{l}\text { Erken Çocuklukta } \\
\text { Sanat Eğitimi }\end{array}$ & Sanat Eğitimi & $\begin{array}{l}\text { Bebeklik } \\
\text { Döneminde Geliş̧im } \\
\text { ve Eğitim }\end{array}$ & $\begin{array}{l}\text { Sosyal Bilgiler } \\
\text { Öğretimi }\end{array}$ \\
\hline & & & $\begin{array}{l}\text { Erken Çocukluk } \\
\text { Dönemi Çevre Eğitimi }\end{array}$ & Çevre Eğitimi & $\begin{array}{l}\text { Erken Çocukluk } \\
\text { Döneminde Gelişim }\end{array}$ & $\begin{array}{l}\text { Türkiye } \\
\text { Coğrafyası ve } \\
\text { Jeopolitiği }\end{array}$ \\
\hline & & & $\begin{array}{l}\text { Erken Çocuklukta } \\
\text { Müzik Eğitimi }\end{array}$ & Müzik Öğretimi & $\begin{array}{l}\text { Çocuğu Tanıma ve } \\
\text { Değerlendirme }\end{array}$ & $\begin{array}{l}\text { Türk Tarihi ve } \\
\text { Kültürü }\end{array}$ \\
\hline & & & $\begin{array}{l}\text { Okula Uyum ve Erken } \\
\text { Okuryazarlık Eğitimi }\end{array}$ & $\begin{array}{l}\text { İlk Okuma ve } \\
\text { Yazma Öğretimi }\end{array}$ & Çocuk Ruh Sağlığ & $\begin{array}{l}\text { İlkokulda } \\
\text { Yabanc1 } \\
\text { Öğretimi }\end{array}$ \\
\hline & & & & Türkçe Öğretimi & & \\
\hline & & & $\begin{array}{l}\text { Erken Çocuklukta Fen } \\
\text { Eğitimi }\end{array}$ & $\begin{array}{l}\text { İlkokulda Temel } \\
\text { Fen Bilimleri } \\
- \text {-.-- }^{-}\end{array}$ & $\begin{array}{l}\text { Çocuk Sağlığı ve İlk } \\
\text { yardım }\end{array}$ & $\begin{array}{l}\text { Din Kültürü ve } \\
\text { Ahlâk Bilgisi } \\
\text { Öğretimi }\end{array}$ \\
\hline & & & & Fen Öğretimi & & \\
\hline & & & & $\begin{array}{l}\text { Fen Bilimleri } \\
\text { Laboratuvar } \\
\text { Uygulamaları }\end{array}$ & & \\
\hline
\end{tabular}


Okul Öncesi ve Sınıf Öğretmenliği Lisans ...

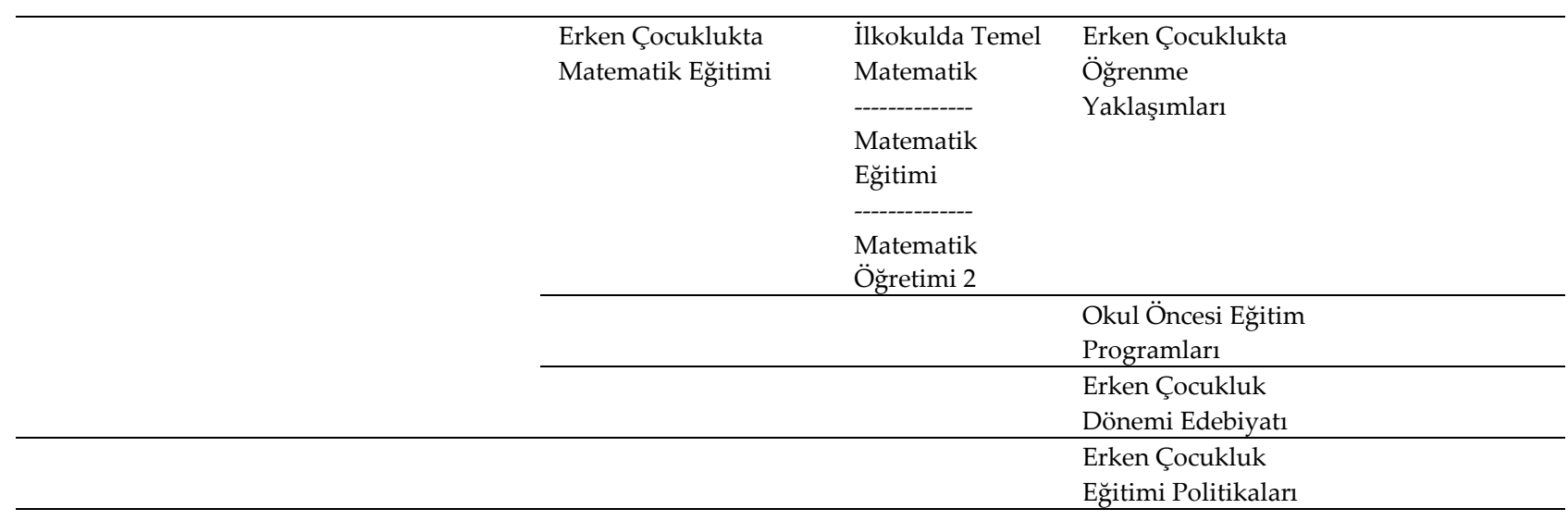

Çevre eğitimi, Fen eğitimi, Matematik Eğitimi, Müzik Eğitimi, Okuma-Yazma Eğitimi, Sanat Eğitimi ve Oyun konularında her iki programda dersler mevcuttur. Bu dersler branşları ortak ancak içerikleri farklı derslerdir. Bu derslerin dışında iki programda tümüyle farklı olan dersler Tablo 2'de verilmiştir.

\section{Seçmeli Derslere Yönelik Bulgular}

İki programda bulunan alan eğitimi seçmeli derslerine yönelik ders sayısı, ortaklık ve farklılık durumlarına ilişkin bulgular Tablo 3'te verilmiştir.

Tablo III

İki programın Alan Eğitimi seçmeli derslerine yönelik bilgiler

\begin{tabular}{|c|c|c|c|c|c|c|}
\hline \multicolumn{2}{|c|}{ Ders Sayısı } & \multirow[b]{2}{*}{$\begin{array}{l}\text { İsim ve İçeriği } \\
\text { Ortak Dersler }\end{array}$} & \multicolumn{2}{|c|}{ İsmi Farklı, İçeriği Ortak Dersler } & \multicolumn{2}{|r|}{ Tümüyle Farklı Dersler } \\
\hline $\begin{array}{l}\text { Okul } \\
\text { Öncesi } \\
\text { Öğr. }\end{array}$ & $\begin{array}{l}\text { Sinıf } \\
\text { Öğr. }\end{array}$ & & $\begin{array}{c}\text { Okul Öncesi } \\
\text { Öğr. }\end{array}$ & Sınıf Öğr. & $\begin{array}{l}\text { Okul Öncesi } \\
\text { Öğr. }\end{array}$ & Sınıf Öğr. \\
\hline \multirow[t]{9}{*}{15} & 12 & $\begin{array}{l}\text { Risk Altındaki } \\
\text { Çocuklar ve Eğitimi }\end{array}$ & $\begin{array}{l}\text { Erken Çocukluk } \\
\text { Eğitiminde } \\
\text { Geleneksel } \\
\text { Çocuk Oyunları }\end{array}$ & $\begin{array}{l}\text { Geleneksel } \\
\text { Çocuk } \\
\text { Oyunları }\end{array}$ & $\begin{array}{l}\text { Aile Eğitimi ve } \\
\text { Katılımı }\end{array}$ & Afetler ve Afet Yönetimi \\
\hline & & $\begin{array}{l}\text { Sınıf İçi } \\
\text { Öğrenmelerin } \\
\text { Değerlendirilmesi }\end{array}$ & $\begin{array}{l}\text { Çocukta Sosyal } \\
\text { Beceri Eğitimi }\end{array}$ & $\begin{array}{l}\text { Sosyal Beceri } \\
\text { Öğretimi }\end{array}$ & $\begin{array}{l}\text { Çocuk ve } \\
\text { Medya }\end{array}$ & Çocuk Edebiyatı \\
\hline & & & $\begin{array}{l}\text { Türk } \\
\text { Kültüründe Aile } \\
\text { ve Çocuk }\end{array}$ & $\begin{array}{l}\text { Türk } \\
\text { Kültüründe } \\
\text { Çocuk ve } \\
\text { Eğitim }\end{array}$ & $\begin{array}{l}\text { Çocukta } \\
\text { Davranış } \\
\text { Yönetimi }\end{array}$ & Çocuk Psikolojisi \\
\hline & & & & & $\begin{array}{l}\text { Çocukta } \\
\text { Hareket } \\
\text { Gelişimi ve } \\
\text { Eğitimi }\end{array}$ & $\begin{array}{l}\text { İlkokul Ders Kitapları } \\
\text { İncelemesi }\end{array}$ \\
\hline & & & & & $\begin{array}{l}\text { Erken } \\
\text { Çocuklukta Dil } \\
\text { ve Kavram } \\
\text { Gelişimi }\end{array}$ & İlkokul Programı \\
\hline & & & & & $\begin{array}{l}\text { Erken } \\
\text { Çocuklukta } \\
\text { Duyu Eğitimi } \\
\end{array}$ & $\begin{array}{l}\text { İlkokulda Alternatif } \\
\text { Eğitim Uygulamaları }\end{array}$ \\
\hline & & & & & $\begin{array}{l}\text { Erken } \\
\text { Çocuklukta } \\
\text { Ritim, Dans ve } \\
\text { Orff Eğitimi } \\
\end{array}$ & Kapsayıcı Dil Öğretimi \\
\hline & & & & & $\begin{array}{l}\text { Erken } \\
\text { Çocuklukta } \\
\text { Yaratıcılık ve } \\
\text { Yaratıcı Çocuk } \\
\text { Etkinlikleri } \\
\end{array}$ & \\
\hline & & & & & Farklı Ülkelerde & \\
\hline
\end{tabular}




\begin{tabular}{ll}
\hline & Erken Çocukluk \\
\cline { 2 - 3 } & Eğitimi \\
& Hastanede \\
& Yatan \\
Çocukların & Eğitimi \\
\hline
\end{tabular}

Alan eğitimi kapsamında seçmeli ders olarak sınıf öğretmenliği programında ikişer kredilik 12, Okul öncesi öğretmenliği programında ikişer kredilik 15 adet ders vardır. Risk Altındaki Çocuklar ve Eğitimi ve Sınıf İçi Öğrenmelerin Değerlendirilmesi dersleri her iki programda da seçmeli olarak yer alan ortak derslerdir. Sınıf İçi Öğrenmelerin Değerlendirilmesi diğer tüm öğretmenlik programlarında da ortaktır.

Okul öncesi öğretmenliği programında yer alan Geleneksel Çocuk Oyunları ve sınıf öğretmenliği programında yer alan Erken Çocukluk Eğitiminde Geleneksel Çocuk Oyunları derslerinin içeriği aynıdır. Sınıf öğretmenliği programında yer alan Çocuk Edebiyatı dersi okul öncesi programı Alan Eğitimi kapsamında yer alan Erken Çocukluk Dönemi Edebiyatı ile aynı içeriğe sahiptir. Bu derslerin dışında iki programda yer alan ve birbirinden tamamen farklı olan alan derslerine Tablo 3'te sağ sütunda yer verilmiştir.

\section{Tartışma}

Okul öncesi ve sınıf öğretmenliği öğretmen yetiştirme programlarının incelenmesi sonucunda, programların ders yoğunluklarının aynı olduğu sonucuna ulaşılmıştır (Meslek Bilgisi \%35, Genel Kültür \%19, Alan Eğitimi \%46). Bununla birlikte, bu benzerlik oranları, bu iki öğretmenliği programına özel değildir. Örneğin, Fen Bilgisi Öğretmenliği programında, ders yoğunlukları Meslek Bilgisi \%34, Genel Kültür \%18, Alan Eğitimi \%48 şeklindedir. Analizden elde edilen bir diğer bulgu ise, meslek bilgisi ve genel kültür derslerinin okul öncesi ve sınıf öğretmenliği programları için ortak olduğu fakat alan dersleri arasında önemli farklılıklar olduğu yönündedir. Alan derslerindeki farklılıklar, erken çocukluk dönemi çocukları ile çalışacak olan okul öncesi ve sınıf öğretmenlerinin, çocukların farklılıklardan doğan potansiyellerini fark edip çok yönlü ihtiyaçlarını karşılayabilmeye yönelik muhtemel yeterlikleri göz önüne alınarak, aşağıda üç temel başlık altında tartışılmıştır.

\section{Çocuğu tanımak yalnızca okul öncesi öğretmen adayları için değil sınıf öğretmeni adayları için de} önemlidir.

Okul öncesi ve sınıf öğretmenliği programlarında yer alan dersler arasındaki en belirgin farkın çocuğu tanıma, çocuk gelişimi konusunda bilgi edinme alanında olduğu görülmektedir. İçerikleri incelendiğinde, okul öncesi öğretmenliği programında 0-8 yaş arası bir çocuğun, açık şekillerde gelişim özellikleri, gereksinimleri ve eğitimine yönelik 3 ders mevcuttur: Erken Çocukluk Eğitimine Giriş, Erken Çocukluk Döneminde Gelişim, Bebeklik Döneminde Gelişim ve Eğitim. Sınıf öğretmenliği programında ise, bu derslere paralel, çocuğun gelişim özellikleri ve eğitimine yönelik herhangi bir dersin olmaması önemli bir eksiklik olarak karşımıza çıkmaktadır. Günümüzde, okul öncesi ve sınıf öğretmenleri örtüşen yaş gruplarına öğretmenlik yapabilmektedir. Bu açıdan düşünüldüğünde, çocuğu tanımaya yönelik derslerin sınıf öğretmenliği programında olmaması, öğretmen adayları için önemli bir eksikliktir. Bu durumun ötesinde, hitap ettiği yaş grubu fark etmeksizin, herhangi bir öğretmenlik alanı için çocuk gelişimine özgü temel bir eğitimin sunulması, öğretmen adaylarının çocuk merkezli eğitim ilkelerini benimseyebilme, çocuğun doğası ve ihtiyaçlarına göre eğitim süreçlerini adapte edebilme becerileri için elzemdir. Alanyazında, önceki yıllarda sınıf öğretmenliği programında yer alan, Erken Çocukluk Eğitimi dersinin, sınıf öğretmenleri adaylarının okul öncesi dönemin önemine ilişkin algıları üzerinde olumlu yönde etkilerinin olduğu belirtilmiş, sınıf öğretmeni adaylarının okul öncesi dönem çocuğunu tanımalarının önemli olduğunun altı çizilmiştir (Kesicioğlu, 2013).

Çocuk Sağlığı ve İlkyardım ve Çocuk Ruh Sağlığı dersleri de benzer şekilde okul öncesi öğretmenliği programında yer alan ancak sınıf öğretmenliği programında bulunmayan derslerdir. Bu durum sinıf öğretmenlerini gerekli ve acil durumlarda çocukların güvenliklerini sağlama, çocukların psikolojik iyi hal ve gereksinimleri konusunda rehberlik edebilmede dezavantajlı bir duruma getirmektedir. Kılıç Özmen'in (2019) sınıf öğretmenliği programı son sınıf öğrencileri ve çalışmakta olan sınıf öğretmenlerinin görüşlerini aktardığı 
çalışmasında yer alan katılımcılar da bu olumsuz durumu dile getirmişlerdir. Öğretmenler ve öğretmen adayları, sınıf öğretmenliği lisans programlarındaki derslerin çocuğu tanıma, çocuğun gelişimi ve psikolojisini anlamaya yönelik bilgiler içerecek şekilde yenilenmesi gerektiğini belirtmişlerdir. Benzer şekilde, Kara ve diğerlerinin (2018) beş yıldan fazla deneyimi olan sınıf öğretmenleri ile yaptıkları çalışma sonuçları da öğretmenlerin Çocuk Sağlığı ve Çocuk Ruh sağlığı derslerinin programa eklenmesi gerektiğini vurguladıklarını ortaya koymuştur.

Çocuk gelişimine ve sağlığına yönelik derslerin yanı sıra, okul öncesi öğretmenliği programında erken çocukluk dönemine özgü öğrenme yaklaşımları ile ilgili ve çocuğu tanıma tekniklerine yönelik Erken Çocuklukta Öğrenme Yaklaşımları ve Çocuğu Tanıma ve Değerlendirme adlı iki ders mevcuttur. Sınıf Öğretmenliği programında bu derslere paralel dersler maalesef yer almamaktadır. Yukarıda belirttiğimiz gibi, sınıf öğretmeni adayları için de eğitim verecekleri yaş grubundaki çocuklara hitap eden öğretim yöntemleri hakkında bilgi sahibi olmaları, çocukların öğrenmelerini gelişimsel ve kültürel açılardan uygun şekillerde değerlendirip gerekli eylemlere geçebilmeleri önemlidir. Bütünsel gelişim açısından, çocuğun gelişiminin uygun ve güvenilir ölçme araçlarıyla değerlendirilmesi ve bu değerlendirmeler sonucunda gelişime uygun eylemlerin planlanması önem arz eder. Sınıf Öğretmenliği programında bu anlamda bir dersin olmaması çocuğun bütünsel gelişimini takip edip destekleme konusunda, sınıf öğretmeni adaylarının yetersiz kalmasına neden olabilir. Bununla birlikte, her iki programda da uygulamaya yönelik derslerin sayısının azalmış olması, öğrencilerin sahada çocukları tanıma olanaklarını da kısıtlamıştır. Uygulama saatleri açısından, lisans programlarımız Avrupa ve Amerika'da bulunan öğretmen yetiştirme programlarının gerisindedir (Aykaç, 2018; Küçükoğlu ve Kızıltaş, 2012). Bu durumun, çocukları tanıma ve uygulama becerisi kazandırma amacıyla, daha fazla uygulama ders saati eklenerek iyileştirilmesi gerekmektedir (Bartan, 2019; Kılıç Özmen, 2019; Sümen Özçakır ve Çağlayan Tuncer, 2013; Şahin, Kartal ve İmamoğlu, 2013).

Erken çocukluk dönemi insan gelişiminde kritik dönemlerden biri olup bireylerin bilişsel potansiyelleri, kişilikleri ve sosyal davranışlarının temelini oluşturmaktadır. Bu dönemde bilişsel, dilsel, sosyal ve psikomotor alanda meydana gelebilecek herhangi bir gelişim farklılı̆̆ının gözlemlenerek, gerekli durumlarda erken müdahalelerde bulunulması sağlıklı birey gelişimi açısından çok büyük önem taşımaktadır. Geç kalınan müdahalelerin çocuk gelişimi üzerinde etkisinin arzu edilen düzeylerde olamadığı yapılan pek çok çalışma ile kanıtlanmıştır (Bergen ve Robertson, 2013; Bredekamp, 2015; Murano, Sawyer ve Lipnevich, 2020). Bu sebeple, okul öncesi öğretmenleri ile birlikte sınıf öğretmenlerinin de geç kalınmadan çocuğu tanıma, çocuk gelişimini değerlendirme konularında alanlarında yetkin olmaları beklenir.

Sonuç olarak, çocuğu her yönüyle tanımak yalnızca okul öncesi öğretmen adayları için değil sınıf öğretmeni adayları için de önemlidir. Örneğin, Yapıcı ve Ulu (2010) 1. sınıf öğretmenlerinin okul öncesi öğretmenlerinden beklentilerini araştırmışlardır. Bu çalışmada, sınıf öğretmenlerinin esasında çocukların gelişimsel özelliklerini yansıtan birtakım davranış ve hazır bulunuşluklarının, çocuğun gelişim döneminden ziyade, okul öncesi öğretmenlerinin eksik sayılabilecek uygulamalarıyla ilişkili olabileceğini düşünmektedirler. Mevcut sınıf öğretmenliği programında çocuğu tanımaya yönelik derslerin eksikliği düşünüldügünde, mezun olacak sınıf öğretmenleri adaylarının da benzer yaklaşımlarda olması muhtemeldir. Çocuğun bütünsel gelişimine dair kapsamlı bir temel eğitim, tüm öğretmen adaylarının düşünme, karar verme ve eyleme geçme süreçlerini şekillendirebileceği için önemlidir.

\section{Erken çocukluk dönemi çocuklarının çok yönlü ihtiyaçlarını karşılayabilmeye yönelik dersler hem okul öncesi hem de sınıf öğretmeni adayları için anlamlıdır.}

Çocuğun bilişsel, sosyal, duygusal, beden ve dil gelişimi birbirinden ayrilmaz bütüncül bir sistemdir (Crosnoe ve diğerleri, 2015; Puma ve diğerleri, 2010). Bu bilgiden hareketle, öğretmen adaylarının çocukların çok yönlü gelişimine dengeli şekillerde destek olabilmesini sağlayan dersler ile karşılaşmaları önemlidir. Sınıf öğretmenliği ve okul öncesini öğretmenliği lisans programları arasındaki en dikkat çekici farklardan biri, sınıf öğretmenliği programında disiplinlere özgü öğretim derslerinin (Fen Öğretimi, Türkçe Öğretimi gibi) yoğunlukta olmasıdır. Okul öncesi öğretmenliği programında ise bu tür dersler daha az sayıda yer almaktadır. Sınıf öğretmenliği programında, disiplinlere özgü öğretim dersleri yoğun iken, bir üst bölümde tartıştı̆̆ımız 
çocuk gelişimine dair dersler ve çocukların çok yönlü gelişimine ilişkin dersler ya yoktur ya da az sayıdadır.

Son yıllarda, ulusal ve uluslararası alanyazında da sık sık eleştirildiği üzere, akademik kaygılar sebebiyle küçük çocuklar gelişimsel uygunluğun gözetilmediği uygulamalarla karşılaşmaktadırlar. Çocuğun bütünsel gelişiminin göz ardı edildiği, beden ve zihin arasında yanıltıcı bir ayrım yapılarak (Dixon, 2011; Tobin, 2004) akademik becerilerin, çok yönlü becerilere göre öncelendiği eğitim uygulamaları yaygınlaşmaktadır (Miller ve Almon, 2009; Parks, 2015; Weisberg, Hirsh-Pasek ve Golinkoff, 2013). Bu çalışmalara göre, öğrenci seçmeye yönelik, çoktan seçmeli merkezi sinav sistemlerinin yaygınlaşmasıyla küçük çocuklara dahi yoğun disiplin odaklı öğretim dersleri sunulmaktadır. Çocuğun çok yönlü gelişimine olanak sağlayacak müzik, yaratıcılık, sanat, spor gibi alanlara yönelik dersler ise geri planda kalmaktadır. Tüm bu uygulamalar ile birlikte, erken çocukluk döneminin en önemli pedagojik öğesi olan oyun, çocukların yaşamlarında daha az yer tutmaya başlamıştır. Özellikle sınıf öğretmenliği programında bu durumun birtakım yansımaları gözlemlenebilir.

Uzun yıllardır okul öncesi öğretmenliği programında olduğu gibi, yeni program ile sınıf öğretmenliği programına da oyun içerikli bir dersin eklenmiş olması önemli ve olumlu bir adımdır. Yapılan araştırmalar oyunun, çocuk gelişim ve eğitiminde etkili olduğu kadar, yetişkinliğe değin yaşamın her döneminde, öğrenme süreci için etkili bir araç olarak kullanılabileceğini ortaya koymaktadır (Benigno ve Farrar, 2012; Gözalan, 2013; Howard ve McInnes, 2012; Kapp, 2012; Türkoğlu ve Uslu, 2016). Okul öncesi öğretmenliği programında yer alan ders, oyunun çocuk için değeri ve oyunun eğitim süreçlerine dâhil edilmesine odaklanmaktadır. Sınıf Öğretmenliği programında yer alan İlkokul Oyun ve Fiziki Etkinlikleri dersi ise içerik açısından farklı olup bu derste daha çok öğretim programıla ilgili bilgiler verilmektedir. Bu açıdan sınıf öğretmenliği programında oyun ve fiziki etkinliklerin öğretimine yönelik bilgilerin yanında oyunun farklı gelişim alanlarına katkısını ve eğitim süreçlerine dâhil edilmesini gösteren etkinlikler içermesi ideal öğretmen becerilerinin kazandırılması açısından gereklidir.

Benzer şekilde, oyun ile birlikte fiziksel gelişim, beden eğitimi, hareket ve beden kullanımın eğitim süreçlerine bütünleştirilmesi konusu çocuk gelişimi ve eğitimi açısından üzerinde durulması gereken bir konudur. Son yıllarda yapılan dikkat çekici çalışmalar, fiziksel etkinlik ve hareketin yoğun olduğu eğitim süreçlerinin çocukların gelişimleri üzerinde olumlu etkileri olduğunu göstermektedir (Vazou ve Skrade, 2017). Hatta bazı çalışmalar, bedenin çocukların düşünme süreçlerini yönetmede merkezi bir rolü olduğuna işaret etmektedir (Lakoff ve Núnez, 2000). Bu sebeplerle, öğretmen adaylarının kuram ve uygulamanın anlamlı şekilde harmanlandığı beden ve hareket eğitimi almaları önemlidir (Sevimli-Çelik, 2020). Yeni program ile birlikte okul öncesi öğretmenliği programında, Çocukta Hareket dersinin zorunlu olmaktan ziyade seçmeli ders kapsamına alınması, sınıf öğretmenliği programında ise bu konuya ilişkin bir dersin olmaması, çocuğun bütünsel gelişimi düşünüldüğünde önemli bir eksiklik olarak karşımıza çıkmaktadır. Hareket ve beden eğitimi ile birlikte, yaratıclık, ritim ve dans odaklı derslerin okul öncesi programı seçmeli ders grubunda olup sınıf öğretmenliği programında bu tür derslerin yer almaması da benzer bir eksiklik olarak değerlendirilebilir.

Çocuğun bütünsel gelişimi ve iyi hali için, okul içi deneyimlerle birlikte, okul dışı deneyimler ve okul ve aile arasındaki ilişkinin niteliği de kritik bir rol oynar (Bronfenbrenner, 1979). Eğitim alanının yaygın çalışma konularından biri olan okul-aile-toplum ilişkileri sayısız çalışmada ele alınarak, etkili okul ve aile iletişiminin çocuğun iyi hali, gelişim ve eğitimi için olumlu etkileri uzun yıllardır ortaya konmaktadır (Şimşek ve Tanaydın, 2002; Van Voorhis, Maier, Epstein ve Lloy, 2013). Bununla birlikte, aile-okul ilişkisi konusunun daha çok 0-6 yaş ya da 0-9 yaş çocukların eğitiminde ele alınırken eğitimin diğer kademelerinde benzer özenle dikkate alınmaması pek çok çalışma ile eleştirilmektedir (Patall, Cooper ve Robinson, 2008). Yeni programda, okul öncesi öğretmenliği programında, okul ve aile işbirliği konusunda bir ders varken, sınıf öğretmenliği programında bu içeriğe sahip bir ders yoktur. Çocukların bütünsel gelişim sürecine olumlu katkı sağlamak için okul, aile ve öğretmen işbirliği konusu tüm öğretmen adayları için önemlidir.

\section{Öğrenme doğum ile başlayan, geçmiş bilgilerin yeni edinilen bilgiler ile ilişki içerisinde olduğu bir süreçtir.}

Farklı disiplinler ve kuramsal bakış açları öğrenmeyi değişen şekillerde tanımlasa da pek çok tanımın 
ortak noktasında öğrenmenin karmaşık ve sürece dayalı bir şekilde gerçekleşiyor olması yer alır. Türkiye'de 2005 yılında yürürlüğe konan ilköğretim programlarının temel felsefesi yapılandırmacı yaklaşıma (Piaget, 1950; von Glassersfeld, 1989) dayandırılmıştır. Bu yaklaşıma göre öğrenme, zihinde var olan ön bilgiler ile yeni edinilen bilgilerin etkileşime girme sürecidir. Öğrenme bu etkileşim neticesinde yeni bilgilerin önceki bilgilerin üzerine inşa edildiği ve/ya önceden var olan bilgilerin zihinde yeniden organize edildiği bir süreçtir. Bu temel öğrenme felsefesinden yola çıkarsak, öğretmenlerin çocukların öğrenme süreçlerini desteklemesinin temel koşullarından biri, çocukların gelişim özelliklerini ve kültürel pratiklerini göz önüne alarak, onların ön bilgileri ve edinebilecekleri potansiyel bilgilerin farkında olarak uygun destek sağlamalarıdır (Vygotsky, 1978). Bu sebeple, erken çocukluk dönemi çocukları ile çalışan okul öncesi ve sınıf öğretmenlerinin, çocukların doğumdan itibaren farklı disiplinlere özgü öğrenme süreçlerinin ne şekillerde gerçekleştiğini anlamaları gerekir. Örneğin, okul hayatına bir okul öncesi eğitim kurumunda başlayan çocuk, ilkokula geldiğinde okul öncesi kurumunda kazandığı öğrenmeleri ön bilgi olarak kullanacaktır. Bu durumda, sınıf öğretmeninin çocuğun okul öncesi dönemden başlayarak hangi temel beceriler ile okula geldiğini anlaması ve öğrencinin olası ön bilgi eksikliklerinde bu durumu fark edip giderecek yeterliliğe sahip olması gerekmektedir.

Öğretmen yetiştirme programları, okul öncesi ve ilkokul kurumları arasında tamamlayıcı ve bütünleştirici bir yapı olması gerektiğini dikkate alarak geliştirilmeli, her iki alana dair öğretmen eğitimi programı da çocukların gelişim ve eğitimini bir bütün olarak ele almalıdır. Mevcut lisans programlarında, Çevre, Sanat, Okuma-Yazma, Fen, Matematik ve Müzik gibi alanların öğretimine ilişkin dersler her iki programda da yer almaktadır. Bununla birlikte, derslerin sayıları ve içerikleri her iki programda farklıdır. Bu ders içeriklerinin, 0-8 yaş çocuklarının dönem özelliklerini kapsamlı şekilde dikkate alan, okul öncesi ve ilkokulda gerçekleştirilen öğrenme etkinliklerine her iki alan öğretmenlerinin de hâkim olmasını sağlayan ve birbirini tamamlayıcı nitelikte olacak şekilde düzenlenmesi gerekmektedir.

Öğretmen adaylarının 0-8 yaş arasındaki çocukların eğitimini bütünsel şekilde desteklemeleri gerekliliğine matematik eğitiminden örnek verilebilir. Erken çocukluk döneminde olan çocukların matematiksel düşünme süreçlerini, Clements ve Sarama (2004) geniş çapta kabul gören boylamsal araştırmalar sonucunda öğrenme yörüngeleri (hypothetical learning trajectories) kuramsal çerçevesi ile açıklarlar. Bu kurama göre, 0-8 yaş arasındaki çocukların matematiksel düşünme süreçleri, doğumdan başlayarak, birbirine bağlı adımlar şeklinde, gelişimsel ilerleme (developmental progression) kaydeder. Bir diğer deyişle, matematikteki her bir farklı konu için (sayı hissi, geometri, ölçme, veri analizi gibi) çocuğun matematiksel düşünme sürecinin takip ettiği bir dizi adım vardır. Çocuğun matematik öğrenmesini desteklemenin koşulu ise, öğretmenin doğumdan başlayarak bu adımlar bütününü bilmesi, çocuğun düşünce biçimini takip ederek her bir adıma uygun desteği sağlayabilmesidir.

Benzer şekilde, çocuklara okuma-yazma becerilerini etkili şekillerde kazandırmanın bir koşulu, çocukların doğumdan itibaren dil gelişimleri ve erken okuryazarlık becerileri hakkında bilgi sahibi olmaktır. Sınıf öğretmeni adayları bu konuda donanım ile yetişirken, Karagöl'ün (2018) mevcut program incelemesine göre okul öncesi öğretmenliği lisans programı çocukların dil gelişimini desteklemede yetersiz görünmektedir. Yunanistan'da yapılan bir araştırma okul öncesi ve birinci sınıf öğretmenlerinin ortak bir dil eğitimi müfredatı uygulamaya ve bu konuda dayanışma içinde çalışmaya olumlu baktıklarını göstermiştir; ancak okul öncesi öğretmenleri, çocuklar üzerindeki akademik baskıyı artırabilmesi sebebiyle, bu duruma daha temkinli yaklaşmışlardır (Apostolou \& Stellakis, 2020). Özetle, benzer ve hatta aynı yaş gruplarına öğretmenlik yapan, birbiri ile örtüşen ve aynı zamanda birbirinin devamı olan okul öncesi ve sınıf öğretmenliği için, 0-8 yaş arasındaki çocukların disiplinlere özgü düşünme ve öğrenme süreçlerini anlayabilecekleri bütünsel bir eğitim sunulması gerekir. Ancak bu şekilde, okul öncesi öğretmenleri sınıflarında farklı öğrenim seviyelerinde olan çocukların ihtiyaçlarına karşılık vermede esnek olabilir ve çocukları daha bilinçli şekillerde ilkokula hazırlayabilirler. Bu duruma paralel şekilde, sınıf öğretmenleri de çocukların ön öğrenme süreçlerinin bilincinde olarak, okul öncesi eğitimi almayan, evde akademik destek gören ya da görmeden okula gelen ve bireysel farklılıkları olan çocukları esnek şekillerde destekleyebilirler. 


\section{Sonuç}

Erken çocukluk ve bütünsel gelişim açısından bakıldığında, 0-8 yaş aralığı hem okul öncesi hem de ilkokul ile örtüştüğünden, okul öncesi ve ilkokul sınıflarında görev yapacak öğretmenlerin daha fazla ortak yeterliğe sahip olması gereklidir. Çocuk, erken çocukluk döneminden çıkmadan ilkokula başlamakta ve bu dönemin 2 yılını bu okullarda geçirmektedir. Okul öncesi ve sınıf öğretmenliği bölümleri birbirinden tamamen bağımsız alanlar değillerdir. Aile tercihlerine göre aynı yaş grubunda olan çocuklardan bir tanesi okul öncesinde, diğeri ise ilkokulda eğitim alabilmektedir. Bu sebeple sınıf öğretmenliği ve okul öncesi öğretmenliği yapacak öğretmen adaylarının her koşula uyum sağlayabilecek yeterliliklere sahip olacak şekilde öğrenme yaşantısı geçirmesi gerekmektedir. Araştırma sonucunda, iki programın çocuğu tanıma ve çocuğun çok yönlü ihtiyaçlarını karşılama alanlarında farklılaştığı ve gelişimsel olarak aynı dönemde olan çocuklara hitap ediyor olmalarının ders içeriklerine yansımadığı sonuçlarına ulaşılmıştır. Bu makalede paylaşılan analiz sonucunda, sınıf öğretmenliği programında, çocuğu tanımaya ve çocuk gelişimine dair derslerin olmaması önemli bir eksiklik olarak belirlenmiştir. Bununla birlikte, okul öncesi öğretmenliği ve sınıf öğretmenliği programlarında çocuğu ailesi ile tanıma ve çocuğu çok yönlü desteklemeye yönelik aile katılımı, beden eğitimi, hareket, yaratıcılık gibi derslerin zorunlu dersler kapsamına alınması önerilmektedir. Matematik, fen, dil eğitimi gibi alan derslerinin ise içeriklerinin 0-8 yaş çocuğunun öğrenme süreci düşünülerek revize edilmesi ve her iki program öğrencilerine bu şekilde sunulması düşünülebilir. Son olarak, yaş, beceri, özel gereksinim, dil, kültür ve sosyo-ekonomik durum gibi farklılıklarının eğitim süreçlerini olumsuz etkilemeden, tüm çocukların bütünsel şekilde desteklenmeleri gerektiğine dair felsefe ve uygulamaları konu alan Çokkültürlü Eğitim, Kapsayıcı Eğitim gibi dersler, okul öncesi ve sınıf öğretmeni adaylarının bu makalede ele alınan mesleki gelişimleri için son derece önemli bir rol oynayabilir.

\section{Yazar(lar)1n Beyanı}

Araştırmacıların katkı oranı beyanı: Araştırmacılar çalışmaya eşit düzeyde katkı sağlamışlardır.

Çatışma beyanı: Makalenin yazarları bu çalışma ile ilgili taraf olabilecek herhangi bir kişi ya da finansal ilişkileri bulunmadığını dolayısıyla herhangi bir çıkar çatışmasını olmadı̆̆ın beyan ederler.

Destek ve teşekkür: Çalışmada herhangi bir kurum ya da kuruluştan destek alınmamıştır.

\section{Kaynaklar}

Akdoğdu, E. ve Uș,un, S. (2017). Sınıf öğretmenliği lisans programının öğretmen adaylarının görüşleri doğrultusunda bağlam, girdi, süreç ve ürün (CIPP) modeli ile değerlendirilmesi. İlköğretim Online, 16(2), 826-847.

Aykaç, N. (2018). Türkiye (Muğla Sıtkı Koçman Üniversitesi) ve Amerika'daki (Kent State Üniversitesi) okul öncesi öğretmen yetiştirme programlarının karşılaştırmalı olarak incelenmesi. Mehmet Akif Ersoy Üniversitesi Ĕ̆itim Fakültesi Dergisi, 48, 624-649.

Apostolou, Z., \& Stellakis, N. (2020). Teachers' perceptions of integrating kindergarten and first-grade primary school language curricula. Journal of Childhood, Education \& Society, 1(2), 87-102.

Barnett, W. S. (2003). Better teachers, better preschools: Student achievement linked to teacher qualifications. NIEER Preschool Policy Matters (2). New Brunswick, NJ: National Institute for Early Education Research.

Bartan, M. (2019). Okul öncesi öğretmen ve öğretmen adaylarının okul öncesi öğretmen yetiştirme lisans programı hakkında görüş ve önerileri. Dumlupınar Üniversitesi Eğitim Bilimleri Enstitüsü Dergisi, 3(1), 2426.

Bekman, S. (1998). Eşit fırsat: Anne - Çocuk Ĕ̆itim Programı'nın değerlendirilmesi. İstanbul: Anne-Çocuk Eğitim Vakfı Yayınları.

Benigno, J. P. ve Farrar, M. J. (2012). Determinants of joint attention in young siblings' play. Infant and Child Development, 21(2), 160-174. 
Bergen, S. ve Robertson, R. (2013). Healthy children, healthy lives: The wellness guide for early childhood programs. Minnesota: RedLeaf Press.

Blank, J. (2010) Early childhood teacher education: Historical themes and contemporary issues. Journal of Early Childhood Teacher Education, 31(4), 391-405.

Bredekamp, S. (2015). Erken çocukluk eğitiminde etkili uygulamalar [Effective practices in early childhood education, $2^{\text {nd }}$ ed.]. (Çev. Hatice Zeynep İnan ve Taşkın İnan). Ankara: Nobel Yayıncllık.

Bronfenbrenner, U. (1979).The ecology of human development. Cambridge: Harvard Üniversitesi Yayınları.

Copple, C. ve Bredekamp, S. (Ed.) (2009). Developmentally appropriate practice in early childhood programs serving children from birth through age 8 (3. bs.). Washington, DC: National Association for Education of Young Children.

Crosnoe, R., Bonazzo, C. ve Wu, N. (2015). Healthy learners: A whole child approach to reducing disparities in early education. Columbia University: Teachers College Press.

Çakıroğlu, E. ve Çakıroğlu, J. (2003). Reflections on teacher education in Turkey. European Journal of Teacher Education, 26(2), 253-264.

Çakmak, E. ve Civelek, F. (2013). Sınıf öğretmenliği lisans programının MEB özel alan öğretmen yeterlikleri açısından incelenmesi. Elektronik Sosyal Bilimler Dergisi, 12(47), 349-367.

Çalışıcı, B. (2019). 2016-2018 yılları arasında Türkiye'de öğretmen yetiştirme politikalarına ilişkin bir değerlendirme (Yayınlanmamış doktora tezi). Hacettepe Üniversitesi, Ankara.

Clements, D. H. ve Sarama, J. (2004). Learning trajectories in mathematics education. Mathematical Thinking and Learning, 6(2), 81-89.

Çaycı, B. (2011). Sınıf öğretmenliği lisans programındaki alan eğitimi derslerinin öğretmen yeterliği üzerindeki etkisinin incelenmesi. Mersin Üniversitesi Ĕ̆itim Fakültesi Dergisi, 7(2), 1-12.

Çoban, A. (2011). Sınıf öğretmenliği lisans programının değerlendirilmesi. Dicle Üniversitesi Ziya Gökalp Ĕ̆itim Fakültesi Dergisi, 16, 28-45.

Dixon, K. (2011). Literacy, power and the schooled body. London and New York: Routledge.

Erdiller, Z. B. ve McMallen, M.B. (2003). Turkish teachers' beliefs about developmentally appropriate practices in early childhood education. Hacettepe University Journal of Education, 25, 84-93.

Erdiller Akın, Z. B. (2013). Examining the beliefs of Turkish pre-service early childhood teachers regarding early childhood curriculum. Journal of Research in Childhood Education, 27(3), 302-318.

Ergün, M. ve Ersoy, O. (2014). Hollanda, Romanya ve Türkiye'deki sınıf öğretmeni yetiştirme sistemlerinin karşılaştırılması. Kastamonu Eğitim Dergisi, 22(2), 673-700.

Gözalan, E. (2013). Oyun temelli dikkat eğitim programının 5-6 yaş çocuklarının dikkat ve dil becerilerine etkisinin incelenmesi (Yayınlanmamış yüksek lisans tezi). Selçuk Üniversitesi, Sosyal Bilimler Enstitüsü, Konya.

Howard, J. ve McInnes, K. (2012). The impact of children's perception if an activity as play rather than not play on emotional elbeing. Child, 38(1), 1-6.

Kamışlı, H. (2019). Evaluation of elementary school teacher education undergraduate program in terms of multicultural education. İlköğretim Online, 18(4), 1539-1549.

Kapp, K. M. (2012). The gamification of learning and instruction: Game-based methods and strategies for training and education. San Francisco: John Wiley \& Sons.

Kara, N., Demir, M. K., Arcagök, S. ve Çavuş, Ş. (2018). Sınıf öğretmenlerinin mesleki gelişimleri açısından sınıf eğitimi lisans programının yeterliliği. Turkish Studies-Educational Studies, 13(19), 1061-1082. 
Karagöl, E. (2018). Dil becerileri eğitimi açısından okul öncesi öğretmenliği lisans programı. Academy Journal of Educational Sciences, 2(2), 159-171.

Karataş, K. (2018). Kültürel değerlere duyarlı eğitim açısından sınıföğretmenliği lisans programının değerlendirilmesi (Yayımlanmamış doktora tezi). Dicle Üniversitesi, Diyarbakır.

Kesicioğlu, O. S. (2013). Sınıf öğretmenliği öğretmen adaylarının okul öncesi eğitime ilişkin algılarının incelenmesi. Elektronik sosyal bilimler dergisi, 12(43), 183-199.

Kılıç, Özmen, Z. (2019). 2018 Sınıf öğretmenliği lisans programının değerlendirilmesi. Journal of Educational Sciences International, 9(2), 521-548.

Küçükahmet, L. (2007). 2006-2007 öğretim yılında uygulanmaya başlanan öğretmen yetiştirme lisans programlarının değerlendirilmesi. Türk Eğitim Bilimleri Dergisi, 5(2), 203-218.

Küçükoğlu, A. ve Kızıltaş, E. (2012). Almanya, Fransa, İngiltere, İtalya, Rusya ve Türkiye okul öncesi öğretmen yetiştirme programlarının karşılaştırılması. İlköğretim Online, 11(3), 660-670.

Lakoff, G. ve Núnez, R.E. (2000). Where mathematics comes from: How the embodied mind brings mathematics into being. New York, NY: Basics Books.

Milli Eğitim Bakanlığ1 [MEB Hayat Boyu Öğrenme Genel Müdürlüğü Göç ve Acil Durum Eğitim Daire Başkanlığı]. (2019). Geçici koruma kapsamı altındaki öğrencilerin eğitim hizmetleri. 26 Mart 2020 tarihinde https://hbogm.meb.gov.tr/mebiysdosyalar/201903/06145652 04-Mart 2019 internetsunu.pdf adresinden erişildi.

Milli Eğitim Bakanlığı Okul Öncesi Eğitim ve İlköğretim Kurumları Yönetmeliği Değişiklik Yapılmasına Dair Yönetmelik (2019, 10 Temmuz). Resmi Gazete (Sayı: 30827) Erişim adresi: https://www.resmigazete.gov.tr/eskiler/2019/07/20190710-6.htm).

Miller, E. ve Almon, J. (2009). Crisis in the kindergarten: Why children need to play in school. College Park, MD: Alliance for Childhood Press.

Murano, D., Sawyer, A. ve Lipnevich, A. A. (2020). A Meta-analytic review of preschool social and emotional learning interventions, Review of Educational Research, 90(2), 227-263.

Nieto, S. (2003). Challenging current notions of "highly qualified teachers" through work in a teachers' inquiry group.Journal of Teacher Education, 54 (5), 386-398.

Olkun, S., Deniz, E., Toran, M., Sarı, M. ve H., Kamışlı, H. (Ed.) (2019). Bütünsel açıdan çocuk. Ankara: Pegem.

Parks, A. N. (2015). Exploring mathematics through play in the early childhood classroom. New York, NY: Teachers College Press.

Patall, E. A., Cooper, H. ve Robinson, J. C. (2008). Parent involvement in homework: A research synthesis. Review of educational research, 78(4), 1039-1101.

Piaget, J. (1950). The Psychology of Intelligence (Çev. M. Piercy ve D. E. Berlyne). London: Routledge \& Kegan Paul. (Original work published 1947)

Puma, M., Bell, S., Cook, R., Heid, C., Shapiro, G., Broene, P. ve Ciarico, J. (2010). Head Start Impact Study: Final Report. Washington, DC: U.S. Department of Health and Human Services, Administration for Children \& Families.

Saracho, O. N. ve Spodek, B. (2007) Early childhood teachers' preparation and the quality of program outcomes. Early Child Development and Care, 177(1), 71-91.

Saracho, O. N. ve Spodek, B. (2013). Introduction: A contemporary researchers vade mecum (redux). O. N. Saracho ve B. Spodek (Ed.), Handbook of research on the education of young children (s. 1-15). New York: Routledge/Taylor and Francis Group. 
Sevimli-Çelik, S. (2020). Moving between theory and practice: Preparing early childhood pre-service teachers for teaching physical education. Journal of Early Childhood Teacher Education. Çevrimiçi ön yayın.

Sümen Özçakır, Ö. ve Çağlayan, T. K. (2013). Öğretmen adaylarının eğitim fakültesinden memnuniyet düzeyleri ve hayal ettikleri eğitim ortamı. Ondokuz Mayıs Üniversitesi Eğitim Fakültesi Dergisi, 32(2), 249272.

Şahin, Ç., Kartal, O. Y. ve İmamoğlu, A. (2013). Okul öncesi öğretmen yetiştirme programı hakkında okul öncesi öğretmen adaylarının görüşleri. Ahi Evran Üniversitesi Kırşehir Ĕ̆itim Fakültesi Dergisi (KEFAD), 14(1), 101-118.

Şimşek, H. ve Tanaydın, D. (2002). İlköğretimde veli katılımı: Öğretmen-veli-psikolojik danışman üçgeni. Ilköğretim Online-Elementary Education Online, 1(1), 12-16.

Şimsek, H. ve Yıldırım, A. (2001). The reform of pre-service teacher education in Turkey. R. G. Sultana (Ed.) Challenge and change in the Euro-Mediterranean region (s. 411-430) içinde. New York: Peter Lang.

Souto-Manning, M. (2013). Multicultural teaching in the early childhood classroom: Approaches, strategies and tools for preschool-2nd grade. New York: Teachers College Yayınları.

Uysal, H., Ozen Altınkaynak, S., Taşkın, N., Akman, B. ve Çağlayan Dinçer, F. (2016). Okul öncesi öğretmeni adaylarının okul öncesi öğretmenliği programına ilişkin metaforik algıları. Cumhuriyet International Journal of Education, 5(3), 1-15.

Tobin, J. (2004). The body in preschool. Liora Bresler (Ed.), Knowing bodies, feeling minds: Embodied knowledge in arts education and schooling (s. 111-125) içinde. Netherlands: Kluwer Academic Press.

Türkoğlu, B. ve Uslu, M. (2016). Oyun temelli bilişsel gelişim programının 60-72 aylık çocukların bilişsel gelişimine etkisi. Uluslararası Ĕ̆itim Bilimleri Dergisi, 3(6), 50-68.

Van Voorhis, F. L., Maier, M. F., Epstein, J. L. ve Lloyd, C. M. (2013). The impact of family involvement on the education of children ages 3-8: A focus on literacy and math achievement outcomes and social-emotional skills. 16 Şubat 2020 tarihinde http://www.mdrc.org/sites/default/files/

The_Impact_of_Family_Involvement_FR.pdf. adresinden erişildi.

Vazou, S. ve Skrade, M. A. (2017). Intervention integrating physical activity with math: Math performance, perceived competence, and need satisfaction. International Journal of Sport and Exercise Psychology, 15(5), 508-522.

von Glasersfeld, E. (1989). Cognition, construction of knowledge, and teaching. Synthese, 80(1), 121-140.

Vygotsky, L. (1978). Interaction between learning and development. M. Cole, V. John Steiner, S. Scribner ve E. Souberman (Ed.), Mind in society: The development of higher psychological processes (s.79-91) içinde. Cambridge, MA: Harvard University Press.

Weisberg, D. S., Hirsh-Pasek, K. ve Golinkoff, R. M. (2013). Guided play: Where curricular goals meet a playful pedagogy. Mind, Brain, and Education, 7(2) 104-112.

Whitebook, M. (2003). Early education quality: Higher teacher qualifications for better learning environments: A review of the literature. Berkeley, CA: Institute of Industrial Relations.

Yapıcl, M. ve Ulu, F. B. (2010). İlköğretim 1. sınıf öğretmenlerinin okul öncesi öğretmenlerinden beklentileri. Kuramsal Ĕ̆itimbilim Dergisi, 3(1), 43-55.

Yıldırım, A. ve Şimşek, H. (2005). Sosyal Bilimlerde Nitel Araştırma Yöntemleri (Güncelleştirilmiş Geliştirilmiş 5. bs.). Ankara: Seçkin Yayıncılık.

Yurdakal, İ. H. (2018). Değişen sınıf öğretmenliği lisans program içeriğinin incelenmesi. Ulakbilge, 6(29), 14831499. 


\section{EXTENDED ABSTRACT}

\section{Introduction}

Given the utmost importance of early years in child development and education, early childhood teacher education is a critical area of examination. In Turkey, early childhood teacher education programs are composed of two different tracks. One track, called pre-school teacher education, offers certification in teaching children from birth-to-kindergarten. The other track, called primary school education, certifies teachers to teach from 1st through 4thgrade. In other words, pre-school and primary school teachers share the responsibility of educating children in the early childhood period. In national teacher education programs, equipping pre-service teachers with knowledge and skills in fulfilling children's individual and cultural needs and recognizing children's potentials has always been a concern. With a recent policy change regarding school entrance, the age of children enrolled in kindergarten, and first-grade classes have widely overlapped. This implementation strengthened the concern of if teachers are being prepared to fulfill the needs of children regardless of their age and individual differences. In this paper, we argue that all teachers working with young children should have the competencies to support children's development and assist in academic learning along with versatile skills about life in areas such as social and emotional abilities, music, arts, and sports. In this research, we overall investigate if pre-school and primary school teachers are trained to have professional skills that complement each other with common professional core competencies. We analyze the similarities and differences of national pre-school and primary school education undergraduate programs. In our analysis, we were guided by the whole child approach, which offers significant potential in the process of determining the competencies and responsibilities of teachers working with early age groups. Accordingly, we discussed possible teacher competencies to meet the holistic educational needs of children within the curricula of the pre-school and primary teacher education programs.

\section{Method}

We utilized a document analysis method (Yıldırım \& Şimşek, 2005) to examine pre-school and primary school teacher programs from the whole child approach. In this process, we followed these steps:

1. Accessing the document and checking its authenticity: The document we analyzed is the booklet titled "Teacher Training Undergraduate Programs". This booklet was published by the Higher Education Council (YÖK) at Ankara University printing house to be implemented starting from the 2018-19 academic year in all public and private universities offering teacher education programs. To check the authenticity of the document, the programs updated on the YÖK official website were examined, and it was ensured that the document contains the up-to-date and correct information.

2. Understanding the documents and the classification of data: In the first stage, we examined the courses included in the pre-school and primary school teacher programs separately, and we categorized the courses under (a) pedagogical knowledge, (b) common core courses, and (c) content knowledge. At this stage, we tabulated the common and different courses of the two programs according to these three titles. To determine whether the commonalities in these three titles belong only to pre-school and classroom teacher programs, we also examined all other teaching programs. In the second stage, we tabulated the course names and contents of the two programs. At this stage, we identified the courses with the same name and content along with the courses with a different name but the same content. In the third stage, considering the names of the courses together with their contents, we tabulated them according to the disciplines they belong to. In the fourth stage, we examined the elective courses related to the three fields, and we listed the common and different courses with their names and content.

3. Analysis of the data: We analyzed the data according to similarities and differences in the two programs. Then, we quantified the data and calculated the similarity rates. We also categorized the courses by considering their names and course contents under titles that can help answer the research question. Based on the data obtained, we made inferences about the two programs. 


\section{Results}

Our initial analysis showed that the course densities of pre-school and primary school education programs are the same (Pedagogical Knowledge 35\%, Common Core 19\%, Content Knowledge $46 \%$ ). However, these similarity rates are not specific to these two teacher education programs. In other teaching programs, for example, in the Science Education program, the course intensities are more or less the same. Another result we obtained from the analysis is that pedagogical knowledge and common core courses are common for preschool and primary school education programs. With that being said, there are important differences between the content knowledge courses in two programs while there exists only one course with the same name and content, and one course with a different name but same content. It has been determined that the number of courses with the same content is seven, and the number of completely different courses is six in primary school teacher education programs and nine in pre-school education program. Drawing on the whole child approach, our main analysis revealed that pre-school and primary school teacher education programs extensively differ in equipping teachers with knowledge about child development and childhood in favor of the pre-school teacher education program. Another main finding of the research manifested discontinuities among these two programs, which ignore the process-oriented nature of children's development and academic learning in different disciplines such as in mathematics and early literacy.

\section{Conclusion}

In Turkey, pre-school and primary school teachers share the responsibility of educating children in the early childhood period while the age of children in pre-school and primary school classrooms overlap. Depending on family preferences, children in the same age group can either receive pre-school or primary school education. Therefore, pre-school and primary school teachers should embrace professional skills that complement each other with common professional core competencies. Pre-school and primary school teacher education programs are not entirely independent fields. For this reason, pre-service teachers in these two tracks should have a learning experience in such a way that they have the qualifications to fulfill the need of all children with varying developmental potentials, and needs. 